\title{
PERILAKU PENCARIAN INFORMASI SEBAGAI SUMBER GAGASAN PEMBUATAN BERITA OLEH WARTAWAN PIKIRAN RAKYAT
}

\author{
Tantyo Hamami ${ }^{1}$, Dian Sinaga ${ }^{2}$, Wina Erwina ${ }^{3}$ \\ 1,2,3 Program Studi Ilmu Perpustakaan Fikom Unpad \\ tantyo.hamami@yahoo.co.id, ${ }^{2}$ dian.sinaga@unpad.ac.id, ${ }^{3}$ wina.erwina@unpad.ac.id
}

\begin{abstract}
This research aims to discuss how the behavior of journalists, especially in daily news paper Pikiran Rakyat Bandung Raya rubric's to search information as an idea in making news. The research methodology was qualitative method with case research approach. The data collection is done by in-depth interviews, observation, and literature. Informants in this research were the twelve journalists in Pikiran Rakyat Bandung Raya Rubric's is selected by snowball sampling techniques with the help of key informants. through key informants, research's get the next informant to be interviewed. The results of this research shows that all informants do several stages of information seeking, there are six greats stages journalist do is stage activities prefix information retrieval, stage activities of election/ selection information topics, the processing step search/ browsing information, the processing step collecting the information, the processing step presentation and a processing step which is flexible journalist that the determination of viewpoint/ news Angle. The results of this research shows that all informants through several stages information seeking. There are six stages journalist do, prefix step of information seeking, the stage of election/selection information topics, the stage of search/browsing information, the stage of collecting the information, the stage of presentation and there is a flexible stage of journalist to determine Angle news.
\end{abstract}

Keywords: Information Seeking Behavior, News-Making, Pikiran Rakyat Bandung Raya Rubric's

ABSTRAK - Penelitian ini bertujuan untuk membahas tentang bagaimana perilaku para wartawan khususnya di rubrik Bandung Raya koran harian Pikiran Rakyat dalam melakukan pencarian informasi sebagai gagasan dalam pembuatan berita. Metodologi penelitian yang digunakan dalam penelitian ini adalah metode kualitatif dengan pendekatan studi kasus. Pengumpulan data dilakukan dengan wawancara mendalam, observasi, dan studi pustaka. Informan dalam penelitian ini merupakan dua belas wartawan yang ada di Rubrik Bandung Raya Pikiran Rakyat yang dipilih melalui teknik Snowball sampling dengan bantuan key informan. Melalui key informan maka peneliti mendapatkan informan selanjutnya untuk di wawancarai. Hasil penelitian ini menunjukkan bahwa semua informan melakukan beberapa tahapan pencarian informasi, terdapat enam tahapan besar yang wartawan lakukan, yaitu tahap kegiatan awal pencarian informasi, tahap kegiatan pemilihan/ seleksi topik informasi, tahap kegiatan penelusuran/penjelajahan informasi, tahap kegiatan pengkoleksian informasi, tahap kegiatan penyajian dan satu tahap kegiatan wartawan yang bersifat fleksibel yaitu penentuan sudut pandang berita.

Kata Kunci: Perilaku Pencarian Informasi, Pembuatan Berita, Rubrik Bandung Raya Pikiran Rakyat

\section{PENDAHULUAN}

Fenomena yang terjadi di daerah wilayah kota bandung, kabupaten bandung, kabupaten bandung barat dan cimahi. Diliput secara mendalam oleh anggota wartawan Pikiran Rakyat Rubrik Bandung Raya sebagai pemenuhan pekerjaan mereka dalam membuat berita. Sebagai contoh berita yang di paparkan di website www.pikiran-rakyat.com tentang "mahasiswa hukum unpas tolak revisi UU KPK dengan cara menggelar aksi demonstrasi di depan kampus, jalan lengkong besar, kota bandung pada tanggal 18 februari 2016. Contoh lain berita yang di liput oleh wartawan Pikiran Rakyat bagian Bandung Raya adalah "Internetan? Keperpustakaan saja" berita ini menjelaskan tentang perpustakaan daerah kota cimahi yang sudah memfasilitasi perpustakaan nya dengan akses internet dengan wi-fi dan bandwitch besar untuk mendukung kegiatan masyarakat memanfaatkan layanan internet. Hal ini membuat pengunjung perpustakaan kota cimahi sendiri. Berita ini diliput 
pada tanggal 19 februari 2016. Dari berita-berita yang peneliti baca di website tersebut, menarik peneliti untuk memahami lebih jauh tentang bagaimana wartawan Pikiran Rkayat bagian bandung raya dalam mencari sumber gagasan untuk pembuatan berita sebagi pemenuhan pekerjaan mereka khususnya daerah Bandung dan Kabupaten bandung dan Cimahi. Setelah membaca berita tersebut muncul beberapa pertanyaan bagaimana cara pencarian informasi yang dilakukan oleh para wartawan tersebut sesuai dengan fakta kejadian yang sebenarnya terjadi di lapangan.

Dalam membuat sebuah berita, wartawan Pikiran Rakyat Rubrik Bandung Raya kerap kali membutuhkan informasi guna menumbuhkan ide atau untuk mendapatkan gambaran tentang objek yang akan diberitakannya. Contohnya ketika wartawan Bandung Raya meliput berita tentang bencana banjir di daerah Bandung, maka wartawan akan mencari sebanyak mungkin informasi tentang banjir yang pernah terjadi di wilayah Bandung sebelumnya, apa penyebab terjadi banjir di wilayah tersebut, pendapat masyarakat Bandung tentang wilayah yang terkena banjir. Apabila setelah di lakukan pencarian informasi, maka diketahui bahwa kejadian banjir ini pernah terjadi sebelumnya dan bagaimana para pihak pemerintah Bandung dalam mengatasinya.

Contoh selanjutnya "Heryawan minta kepala daerah langsung bekerja" enam pasang bupati, wakil bupati, walikota dan wakil walikota mengucapkan sumpah janji yang di bombing gubernur jabar Ahmad Heryawan, pada pelantikan bupati dan wali kota, serta wakil bupati dan wakil walikota hasil pemilihan kepala daerah serentak tahun 2015, di gedung merdeka, jalan asia-afrika, kota bandung tanggal 17 februari 2016. "Setelah pelantikan ini, saudara-saudari bupati, wakil bupati, wali kota dan wakil wali kota diminta langsung bekerja tanpa jeda dan tidak ada transisi untuk mewujudkan janji kampanye." Kata heryawan dalam sambutan pelantikan enam kepala daerah jawa barat di gedung merdeka. Dari berita yang di paparkan wartawan Pikiran rakyat Rubrik Bandung Raya akan mencari informasi sebelum acara itu di mulai kapan enam pasang calon bupati, wakil bupati, wali kota dan wakil walikota akan datang. Bagaimana persiapan yang akan diselenggarakan sebelum acara. Siapa saja 6 pasang calon tersebut. Informasi-informasi lainnya yang memiliki nilai bagi wartawan Bandung Raya sebelum acara tersebut berlangsung.

Beberapa contoh kasus yang telah disebutkan sebelumnya menyebutkan bahwa pada dasarnya seorang wartawan juga membutuhkan informasi guna menunjang ketepatan, kebenaran dan keberhasilan sebuah berita yang dibuatnya. Hal tersebut agar para wartawan Pikiran Rakyat Rubrik Bandung Raya tidak keliru dan memiliki kesalahan fatal karena berita yang dibuat haruslah sesuai dengan realita atau kenyataan. Tidak hanya itu harus sesuai dengan kode etik jurnalistik.

Pada kegiatan ini pengguna menyadari bahwa terdapat kebutuhan informasi yang harus dipenuhi guna kelangsungan kegiatan sehari-hari penggunanya. Hal tersebut juga serupa dengan yang dialami oleh wartawan Pikiran Rakyat Rubrik Bandung Raya, dimana mereka merasa membutuhkan sebuah informasi guna sebagai gagasan pembuatan berita. Karena pada objek yang saya teliti wartawan dituntut untuk mencari dan menyebarkan informasi tentang berita atau kejadian di wilayah Bandung dan sebagainya harus sesuai dengan kenyataan pada saat di lapangan. 
Untuk itulah mereka melakukan pencarian informasi, apa yang menjadi kenginannya serta tahapan-tahapan yang perlu dilakukan guna mendapatkan informasi sesuai dengan yang dicari.

\section{TINJAUAN PUSTAKA}

Dewasa ini informasi merupakan salah satu hal pokok yang dibutuhkan oleh seluruh kalangan masyarakat baik itu dari kalangan anak-anak sampai dengan orang tua. Perkembangan dan kemajuan teknologi informasi menyebabkan perubahan hidup manusia dalam berbagai bidang. Setiap hari bahkan setiap jam banyak informasi baru yang di update.

Salah satu profesi yang menyediakan informasi untuk kalangan masyarakat adalah Wartawan.

"Wartawan disebut juga sebagai jurnalistik, secara sederhana jurnalistik diartikan sebagai kegiatan yang berhubungan dengan pencatatan atau pelaporan setiap hari. Dalam kamus, jurnalistik diartikan sebagai kegiatan menyiapkan, mengedit, dan menulis untuk surat kabar, majalah atau surat kabar lainnya“(Assegaff 1982, 9).

Dalam dunia jurnalistik, seorang wartawan memiliki peran penting dalam menyampaikan informasi kepada publik. Setiap data dan fakta yang diperoleh dalam peliputan berkaitan dengan kepentingan umum. Maka dalam kegiatan jurnalistiknya itu dilakukan demi kepentingan publik bukan untuk pihak tertentu. Hal ini terkait akan kebutuhan masyarakat terhadap informasi yang semakin meningkat seiring perkembangan teknologi komunikasi belakangan ini. Masyarakat membutuhkan informasi yang komprehensif. Produk informasi yang dihasilkan oleh waratawan adalah berita. Berita dalam definisi jurnalistik.
"Dikatakan berita adalah laporan tentang fakta atau ide yang termasa, yang dipilih oleh staf redaksi suatu harian untuk disiarkan, yang dapat menarik perhatian pembaca, entah karena dia luar biasa, entah karena penting atau akibatnya, entah pula karena mencakup segi-segi human interest seperti humor, emosi dan ketegangan" (Assegaff 1982, 24).

Salah satu pers yang berperan dalam menyebarkan karya wartawan yaitu Pikiran Rakyat. Pikiran Rakyat yang pusatnya berada di bandung merupakan lembaga sosial yang sudah berdiri sejak lama yang berperan dalam media cetak Koran. Informasi yang disajikan oleh Pikiran Rakyat yaitu informasi tentang seputar ekonomi, pendidikan, olahraga, bandung raya. Pikiran rakyat sendiri memiliki wartawan professional dan teruji kinerjanya dilihat dari berita yang di parparkan di Koran pikiran rakyat, tidak hanya itu wartawan pikiran rakyat mempunyai banyak prestasi dalam bidang journalism. Seperti wartawan yang berada dalam pengulasan berita tentang bandung raya. Salah satu wartawan Pikiran Rakyat Rubrik Bandung raya yang memperoleh penghargaan Adinegoro tahun 2014 untuk kategori jurnalistik indepth reporting (berita mendalam), dengan judul karya menyoal anggaran pendidikan 20 persen. Penghargaan Adinugoro yang diperoleh oleh Trijoko Heriyadi menjadi prestasi bagi Rubrik Bandung Raya Wartawan Rubrik Bandung Raya dibagi menjadi daerah Kota Bandung, Kabupaten Bandung Barat, Kabupaten Bandung, dan Cimahi. Berita yang di cari oleh wartawan yaitu berita tentang kriminal, peliputan eksekutif dan legislatif pemerintah provinsi jabar dan Pemerintahan Kota Bandung, peliputan tentang seputar kemenkumham dan berita isu-isu perkotaan yang 
lainya tidak termasuk dalam bagian pendidikan, olahraga, ekonomi. Dalam hal ini peneliti tertarik untuk mencari tahu secara mendalam tentang perilaku pencarian informasi wartawan bagian Bandung Raya. Hal lain yang membuat peneliti tertarik karena wartawan Rubrik Bandung Raya memiliki wartawan yang mendapat penghargaan Adinugoro yang menjadi prestasi bagi Rubrik Bandung Raya Pikiran Rakyat, hal ini juga yang membedakan Rubrik Bandung Raya Pikiran Rakyat dengan Rubrik di Pers media cetak koran lainnya. Selain itu lebih banyak turun di lapangan dibandingkan dengan wartawan Pikiran Rakyat Rubik Ekonomi, Olahraga, dan Pendidikan. Karena berita yang disampaikanpun berita terhangat yang akan dipilih dan di masukan kekoran untuk di terbitkan setiap hari di Koran Pikiran Rakyat, tidak hanya itu berita juga akan di masukan di dalam website resmi Pikiran Rakyat www.pikiran-rakyat.com.

\section{METODE PENELITIAN}

Penelitian ini merupakan penelitian dengan mengguanakan metode kualitatif. Peneliti memilih penelitian kualitatif karena pada penelitian ini peneliti berusaha mengungkapkan pengalaman seseorang mengenai sebuah fenomena, berkaitan dengan perilaku pencarian informasi sebagai sumber menemukan gagasan dalam pemenuhan pekerjaannya yaitu pembuatan berita oleh Wartawan di Pikiran Rakyat Rubrik Bandung Raya. Metode kualitatif dapat digunakan untuk memahami serta mengungkap apa dibalik fenomena itu.

Penelitian ini menggunakan pendekatan studi kasus yaitu membahas bagaimana perilaku pencarian informasi oleh Wartawan Pikiran Rakyat Rubrik Bandung Raya dalam pembuatan berita. Wartawan Rubrik Bandung Raya harus setiap hari mencari informasi ter update untuk dijadikan berita yang akan ditampilkan di surat kabar Harian Pikirian Rakyat. Rubrik Bandung Raya adalah wartawan yang paling banyak turun lapangan dibandingkan dengan wartawan rubrik pikiran rakyat lainnya, dikarenakan mereka harus mengumpulkan berita untuk dikirimkan ke redaktur setiap harinya.

\section{HASIL DAN PEMBAHASAN}

Pada penelitian ini peneliti mengacu pada teori Kulthau (dalam Fisher 2008, 230) dalam modelnya Kulthau menggambarkan kegiatan pencarian informasi merupakan proses pengembangan/pembangunan yang dilalui seseorang dari tahap ketidakpastian menuju tahap pemahaman. Langkah yang bergabung dalam tahapan ini, yaitu inisiation, selection, exploration, formulation, collection, and presentation.

Terdapat dua belas informan yaitu total wartawan yang berada di rubrik bandung raya. Sedangkan triangulasi yang digunakan yaitu seorang redaktur rubrik bandung raya pikiran rakyat. Perilaku pencarian informasi wartawan rubrik bandung raya pikiran rakyat dilakukan melalui lima tahap yaitu tahap kegiatan awal pencarian informasi, tahap kegiatan pemilihan seleksi topik informasi, tahap kegiatan penelusuran atau penjelajahan informasi di lapangan, tahap kegiatan pengkoleksian informasi, tahap kegiatan penyajian informasi dan terdapat satu tahapan yang bersifat fleksibel bisa terjadi atau dilakukan pada tahap pemilihan/seleksi topik informasi, tahap kegiatan penelusuran/ penjelajahan, dan tahap kegiatan pengkoleksian informasi. 
Tahapan kegiatan awal pencarian informasi merupakan tahap awal dalam melakukan pencarian informasi untuk gagasan dalam pembuatan berita. Seiring dengan pembuatan berita yang dilakukan wartawan akan muncul perbedaan kebutuhan informasi sesuai dengan perkembangan peristiwa atau kejadian di suatu tempat atau wilayah sesuai dengan kebutuhannya. Pada tahapan ini kebutuhan informasi sudah mulai dirasakan dlihat dari latar belakang atau alasan yang mendasari wartawan dalam pencarian informasi yaitu karena tuntutan pekerjaan sebagai profesi wartawan, rasa keingintahuan dan untuk menambah pengetahuan bagi wartawan sendiri, untuk kepentingan masyarakat, karena dorongan sosial diri sendiri dan hobi dalam menulis. Latar belakang tersebut akan berpengaruh pada konten berita yang mereka buat akan menjadi bervariasi dan berbeda dengan wartawan di pers lainnya. Semakin baik dan bagus berita yang dibuat untuk disebarkan kemasyarakat, semakin banyak pula timbul rasa percaya oleh masyarakat terhadap hasil berita yang dibuat oleh wartawan. Dari latar belakang wartawan ini akan muncul tindakan awal dalam mendapatkan topik awal informasi yang digunakan untuk pembuatan berita yaitu dari penugasan redaktur, jaringan masyarakat, jadwal persidangan pengadilan, media sosial dan browsing di internet, melakukan diskusi sesama wartawan dan bagian humas kantor pemerintahan.

Tahap selanjutnya yaitu pemilihan/seleksi topik informasi, pemilihan topik diawali dengan wartawan mengetahui terlebih dahulu topik informasi apa saja yang dapat mereka cari untuk dijadikan berita. Topik umum yang dicari yaitu tentang public service atau pelayanan kemasyarakat, suatu peristiwa baik itu bencana alam, kasus kriminal, kegiatan kewilayahan dan juga isu-isu wilayah sesuai dengan penempatan masing-masing wartawan. Penempatan wartawan Rubrik Bandung raya di bagi menjadi empat wilayah yaitu Kota Bandung, Kabupaten Bandung, Kabupaten Bandung Barat dan Cimahi. setelah wartawan mengetahui topik umum yang akan mereka cari, wartawan memikirkan apa saja yang menjadi pertimbangan dalam penentuan pemilihan topik informasi.

Pertimbangan-pertimbangan tersebut antara lain menentukan topik umum informasi yang dicari dengan pertimbangan dari nilai berita, informasi yang dicari harus berimbang dan sesuai dengan standar pikiran rakyat, dan informasi yang dicari bisa menimbulkan kepuasan terhadap diri sendiri. setelah memikirkan apa saja yang menjadi pertimbangan dalam pebuatan berita, selanjutnya wartawan akan melakukan tindakan dalam pemilihan/seleksi topik umum informasi. Tindakan ini dilakukan untuk mengecek kebenaran dari topik awal informasi yang diterima atau sedang dicari. Tindakan tersebut yaitu melakukan kroscek berita-berita sebelumnya melalui media sosial dan browsing di internet, diskusi sesama wartawan dan menanyakan langsung ke pihak-pihak yang memberikan informasi. Pada tahapan pemilihan/seleksi informasi akan muncul tahapan tindakan dalam menentukan sudut pandang berita atau fokus informasi yang dicari. Penentuan sudut pandang pada saat sebelum ke lapangan atau saat menyeleksi topik awal informasi hanya berupa proyeksi awal atau gambaran awal wartawan, dalam menetukan sudut pandang berita. Sudut pandang berita dapat ditentukan dengan menganalisis dari hasil pengecekan berita-berita sebelumnya. Fokus informasi harus sesuai dengan 
pertimbangan pada tahap pemilihan ini yaitu dari nilai berita dan standar dari pikiran rakyat.

Setelah wartawan menentukan topik informasi yang akan dicarinya, tahapan selanjutnya yaitu tahap kegiatan penelusuran/ penjelajahan informasi dilapangan. Pada tahap ini wartawan memikirkan apa saja fasilitas yang digunakan untuk mendukung penelusuran informasi. Fasilitas yang mendukung dalam penelusuran adalah note book, tape recorder, kamera dan hanphone sebagai pengganti fungsi dari ketiga alat tersebut. Setelah mempersiapkan fasilitas yang digunakan, wartawan akan melakukan tindakan dalam mendapatkan informasi yang diperoleh sesuai dengan topik, tindakan tersebut dengan melakukan observasi pemantauan kejadian selama dilapangan, melakukan wawancara dengan narasumber yang berkompeten dan melakukan penelusuran dokumen yang di dapat dari lapangan. Dalam tahapan ini peneliti juga menanyakan kendala yang dialami wartawan dalam melakukan penelusuran informasi, kendala-kendala tersebut dikarenakan dua faktor yaitu internal dan eksternal. Faktor internal yaitu yang berasal dari diri wartawan sendiri yaitu rasa malas dan kesehatan tubuh yang kurang baik atau sakit, sedangkan faktor eksternalnya yaitu faktor teknis yang dialami selama dilapangan pengaruh cuaca, bencana alam dan kesulitan dalam mencari dan menghubungi narasumber yang dianggap berkompeten.

Pada tahap kegiatan penelusuran/ penjelajahan informasi dilapangan dapat muncul juga tindakan wartawan dalam mentukan sudut pandang berita atau fokus informasi yang dicari. Penentuan sudut pandang pada tahapan ini dapat terjadi dikarenakan adanya perubahan dari penentuan sudut pandang sebelumnya pada tahap pemilihan/seleksi informasi, terdapat pernyataan atau informasi yang diberikan dari narasumber yang diwawancarai dianggap menarik dan meyakinkan oleh wartawan sendiri. Penentuan sudut pandang pada tahap ini diperuntukan untuk wartawan memperdalam atau mengeksplor lebih dalam terhadap fokus informasi yang ditentukan. Penentuan sudut pandang dapat ditentukan dengan menggunakan insting yang dimiliki masingmasing wartawan, insting ini didapat dari pengalaman selama wartawan bekerja.

Kegiatan yang selanjutnya dalam tahapan perilaku pencarian informasi adalah tahap kegiatan pengkoleksian informasi. Pada tahap ini wartawan memikirkan bentuk atau format penerimaan informasi yang didapat, bentuk atau format penerimaan ini berupa hasil observasi pemantauan, hasil wawancara dan hasil dokumen yang didapat dilapangan penelusuran informasi. setelah mendapatkan berbagai bentuk atau format penerimaan informasi, wartawan akan melakukan tindakan menganalisis informasi yang didapat yaitu mentranskrip informasi yang didapat seperti mentranskrip hasil wawancara narasumber. Memasukkan hasil observasi dan dokumen yang dianggap penting dan dibutuhkan sesuai dengan sudut pandang berita yang telah ditentukan sebelumnya, hal tersebut hanya sebagai penambahan data untuk pembuatan berita. selain itu peneliti juga menanyakan upaya wartawan dalam melakukan penyimpanan informasi yang telah diperoleh, upaya tersebut dengan menyimpan di laptop, handphone, email dan server pikiran rakyat, penyimpanan informasi ini dilakukan guna untuk melakukan pencarian kembali apabila informasi tersebut dibutuhkan.

Selain bisa dilakukan pada kedua tahapan yaitu penyeleksian informasi dan penelusuran informasi, tindakan dalam penentuan sudut 
pandang berita juga bisa muncul atau dilakukan pada tahapan pengkoleksian informasi. Tindakan wartawan dalam menganalisis informasi untuk dijadikan sudut pandang pun juga sama pada tahapan penyeleksian informasi. Cuma perbedaannya terdapat pada tindakannya dalam menentukan sudut pandang berita dilihat dari hasil informasi yang telah di dapatkan. Penentuan sudut pandang berita pada tahapan ini merupakan tindakan terakhir dalam memastikan fokus informasi untuk pembuatan berita, hal ini dapat terjadi dikarenakan wartawan masih belum menentukan atau merasa kebingungan terhadap topik informasi yang ingin dijadikan sudut pandang berita, sehingga wartawan melakukan konsultasi dengan redaktur rubrik bandung raya menanyakan topik mana yang bagus untuk dijadikan sudut pandang berita. selain itu penentuan sudut pandang dapat terjadi karena adanya perubahan sudut pandang berita yang telah ditentukan sebelumnya yaitu pada tahap pemilihan dan penelusuran informasi. Perubahan ini terjadi dikarenakan pada saat wartawan membaca hasil informasi yang didapatkan selama pencarian, terdapat informasi yang dianggap menarik dan meyakinkan oleh wartawan. Kekurangan mentukan sudut pandang berita pada tahapan ini adalah wartawan melakukan pencarian kembali apabila terjadi kekurangan informasi tentang sudut pandang berita yang ditentukan tadi.

Setelah melakukan tahapan-tahapan sebelumnya dalam pencarian infromasi, kegiatan selanjutnya adalah tahapan kegiatan penyajian informasi. kegiatan ini merupakan tahapan terakhir dalam proses perilaku pencarian informasi. Kegiatan penyajian informasi terdiri dari tindakan wartawan dalam mengolah informasi yang telah diperoleh selama pencarian informasi untuk kemudian selanjutnya akan disajikan dalam bentuk berita. Tindakan tersebut antara lain membuat berita dengan unsur $5 \mathrm{w}$ 1h (what, who, when, where, why dan how). Pertimbangan penyajian berita dilihat dari kuantitas jumhlah alenia untuk ruang penempatan berita yang akan di cetak dikoran. Panjang berita biasanya yaitu terdiri 15 alenia atau paragraf. Pada saat membuat berita akan ada pemberitahuan dari redaktur bandung raya melalui group media sosial whats up ataupun secara personal tentang jumlah penempatan berita yang akan di cetak untuk besok harinya. Pengumpulan berita oleh wartawan dilakukan dengan mengirim melalui email ke Redaktur Bandung Raya. Setelah melakukan pengiriman, berita tersebut masih harus diubah lagi oleh Redaktur Bandung Raya apabila terjadi kepanjangan atau kekurangan paragraf terhadap berita yang dibuat. Redaktur akan menghubungi kembali wartawan tersebut untuk mengubahnya kembali apabila terjadi kekurangan terhadap berita. Selain itu peneliti juga menanyakan perasaan yang timbul setelah menyelesaikan pencarian informasi dan membuat berita, wartawan rubrik bandung raya merasakan perasaan lega, puas, kesal dan penasaran yang berkelanjutan setelah melakukan hal tersebut.

\section{SIMPULAN}

Berdasarkan apa yang telah peneliti sampaikan pada bab empat dari hasil penelitian dan pembahasan mengenai perilaku pencarian informasi wartawan rubrik bandung raya pikiran rakyat, maka didapat beberapa kesimpulan sebagai berikut:

(1) Pada tahap kegiatan awal pencarian informasi, 
terdapat penemuan mengenai berbagai macam latar belakang yang mendasari kebutuhan informasi pada wartawan, yaitu bahwa latar belakang wartawan dalam mencari informasi tidak terlepas dari tuntuntan pekerjaan mereka, kepentingan masyarakat, rasa ingin tahu dan menambah pengetahuan, dikarenakan dorongan sosial wartawan, dan dikarenakan hobi dalam menulis. Pada tahap ini tidakan awal yang dilakukan adalah mendapatkan topik awal informasi dari penugasan redaktur, melakukan diskusi dengan sesama wartawan dan redakturnya untuk menambah wawasan terhadap informasi yang akan mereka cari, media sosial serta internet, humas kantor pemerintahan, dan jaringan masyarakat komunitas serta organisasi kewartawanan.

(2) Tahap berikutya kegaiatan pemilihan/seleksi informasi, diawali dengan wartawan mengetahui terlebih dahulu topik umum informasi apa saja yang akan mereka cari untuk dijadikan berita. Topik umum yang dicari harus sesuai dengan penempatan wilayah masing-masing yakni wartawan wilayah Kota Bandung antara lain Pemerintah Kota Bandung, Pemerintahan Provinsi Jawa Barat, Pengadilan Umum Kota Bandung, Kabupaten Bandung, Kabupaten Bandung Barat, dan Cimahi. Topik umum yang dicari antara lain tentang public service atau pelayan kemasyarakat, suatu peristiwa baik itu bencana alam, kasus kriminal, kegiatan kewilayahan, dan juga isu-isu wilayah. Pertimbangan wartawan dalam memyeleksi topik umum informasi antara lain adalah nilai berita (news value), informasi yang dicari harus berimbang sesuai dengan standar Pikiran Rakyat, dan informasi yang bisa menimbulkan kepuasan terhadap diri sendiri yang memberikan pengaruh kepada masyarakat yang membaca setelah berita ini dibuat. Tindakan yang dilakukan wartawan dalam memilih topik umum antara lain adalah melakukan kroscek berita-berita sebelumnya melalui browsing internet untuk pengembangan berita, kroscek media sosial melakukan pengecekan dengan melihat group media sosial yang wartawan miliki untuk mencari topik informasi, diskusi sesama wartawan dan menanyakan langsung ke pihak-pihak yang memberikan informasi. Selain melakukan tindakan tersebut, wartawan juga melakukan koordinasi antar sesama wartawan Rubrik Bandung Raya khususnya untuk wartawan penempatan wilayah yang sama, hal ini dilakukan untuk menghindari terjadinya kesamaan topik informasi yang akan mereka telusuri.

(3) Tahap selanjutnya kegiatan penelusuran/ penjelajahan informasi dilapangan wartawan menggunakan berbagai macam fasilitas guna untuk mendukung penelusuran selama dilapangan. Sesuai dengan perkembangan teknologi pada zaman sekarang ini, wartawan menggunakan smartphone sebagai peganti fungsi dari note book, tape recorder, dan camera. Tindakan yang dilakukan dalam penelusuran informasi adalah melakukan observasi yakni pemantauan kejadian selama dilapangan, melakukan wawancara dengan narasumber yang berkompeten dan penelusuran dokumen yang didapat dari lapangan. Sedangkan kendala yang dialami oleh wartawan berasal dari faktor internal yaitu berasal dari diri wartawan sendiri dan faktor eksternal yaitu berasal dari teknis pekerjaan yang dilakukan selama di lapangan. 
(4) Tahapan selanjutnya adalah penentuan sudut pandang berita sebagai fokus informasi. Pada tahapan ini bersifat fleksibel, dikatakan fleksibel karena dapat terjadi atau dilakukan pada tahapan kegiatan pemilihan/seleksi informasi, tahapan kegiatan penelusuran/ penjelajahan informasi dan tahapan pengkoleksian informasi.

(5) Tahapan pengkoleksian informasi, Pada tahapan ini bentuk atau format penerimaan informasi berupa hasil observasi, hasil wawancara dan hasil dokumen. Setelah mendapatkan bentuk atau format penerimaan informasi wartawan akan melakukan tindakan menganalisis informasi tersebut dengan cara mentranskrip hasil wawancara narasumber, dan memasukkan hasil observasi serta dokumen yang dianggap penting dan dibutuhkan sesuai dengan sudut pandang berita yang telah ditentukan sebelumnya. Selain itu referensi buku juga dapat ditambahkan untuk memperkaya informasi berita yang akan dibuat. Upaya pengkoleksian informasi dengan menyimpan di laptop, handphone, email dan server Pikiran Rakyat Pada tahap terakhir yaitu kegiatan penyajian informasi para wartawan mengolah informasi yang diperoleh untuk kemudian disajikan dalam bentuk berita. Tindakan yang dilakukan membuat berita dengan unsur $5 \mathrm{w}$ 1h (what, who, when, where, why dan how) dan juga kuantitas jumhlah alenia yang digunakan untuk ruang penempatan berita yang akan di cetak dikoran. Pada saat membuat berita akan ada pemberitahuan dari redaktur bandung raya melalui group media sosial whats up ataupun secara personal tentang jumlah penempatan berita yang akan di cetak untuk besok harinya. Pengumpulan berita oleh wartawan dilakukan dengan mengirim melalui email ke Redaktur Bandung Raya. perasaan yang timbul setelah menyelesaikan pencarian informasi dan membuat berita, wartawan merasakan perasaan lega, puas, kesal dan penasaran yang berkelanjutan setelah melakukan hal tersebut.

\section{DAFTAR PUSTAKA}

Assegaff, Dja'far H.(1982). Jurnalistik Masa Kini. Jakarta: Ghalia Indonesia.

Fisher, A. (2008). Berpikir Kritis: Sebuah Pengantar. Jakarta: Airlangga

HM, Zaenuddin. (2011). The Journalist. Bandung: Simbiosa Rekatama Media.

Khairunissa. (2015). Perilaku Pencarian Informasi Sebagai Sumber Gagasan Oleh Seniman Mural. Skripsi Sarjana Unpad Ilmu Informasi Perpustakaan. Diakses pada 12 februari 2016.

Kuhlthau, Carole Collier. (2007). Information Search Process. http://comminfo.rutgers. edu/ kuhlthau/information_search_process.ht

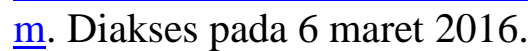

Kulthau, Carole Collier. (1991). Iside the searching process information searching from the users perspective. Journal of the American soecity for information science. Vol 42 no.5.361-371. http://searchproguest.com. Diakses pada 12 maret 2016.

Moleong, Lexy J. (2014). Metode Penelitian Kualitatif. Bandung: Rosdakarya.

Pendit, Putu Laxman. (2006). Ragam Teori Informasi. http://eprints.rclis.org/10294 /1/Ragam_Teori_Informasi.pdf. Diakses pada 11 februari 2016.

Rachman, Arief. (2015). Perilaku Informasi Pengguna Tunanetra Dalam Memenuhi Kebutuhan Belajar: Studi Kasus Di Perpustakaan Braile Bandung. Skripsi Sarjana Unpad Ilmu Informasi Perpustakaan. Diakses pada 9 Maret 2016.

Sugiyono. (2009). Memahami Penelitian Kualitatif. Bandung: Alfabeta. . (2012). Metode Penelitian Kuantitatif Kualitatif dan $R \& D$. Bandung: Alfabeta.

Suhandang, Kustadi. 2004.Pengantar Jurnalisti. Bandung: Nuansa Cendekia.

Sumadiria, AS Haris. (2005). Jurnalistik Indonesia. Bandung: Simbiosa Rekatama Media. 
Sutanta, Edhy. (2003). Sistem Informasi Manajemen. Yogjakarta: Graha Ilmu.

Wilson, TD. (1991). Models In Information Behaviour Research. http://www.informat ionr.net/tdw/publ/papers/1999JDoc.html. diakses pada 10 april 2016.

Yin, Robert K. (2014). Studi Kasus Desain dan Metode. Depok: Raja Grafindo Persada.

Yusuf, Pawit M. (2012). Ilmu Informasi, Komunikasi dan Kepustakaan. Jakarta: Bumi Aksara.

(1995). Pedoman Praktis

Mencari Informasi. Bandung: Remaja Rosdakarya.

(2009). Ilmu Informasi, Komunikasi, dan Kepustakaan. Jakarta: Bumi Aksara.

Yusup, Pawit M. dan Priyo Subekti. (2010). Teori dan Praktik Penelusuran Informasi. Bandung: Remaja Rosdakarya. 